\title{
Comparison of Different Methods of Crop Straw Disposal Based on SWOT Analysis
}

\author{
Fujun Cui ${ }^{1, a}$, Hefang Wang ${ }^{1, b}$, Zhixiang Jiang ${ }^{2, \mathrm{c}}$ and Hao Zheng ${ }^{1, \mathrm{~d}, *}$ \\ ${ }^{1}$ College of Environmental Science and Engineering, Ocean University of China, Qingdao 266100, \\ China \\ ${ }^{2}$ College of Environmental Science and Engineering, Qingdao University, Qingdao 266071, China \\ afujuncui@ouc.edu.cn, bwhfine@126.com, cyifeng501@sina.com, dzhenghao2013@ouc.edu.cn \\ Corresponding author: Hao Zheng, dzhenghao2013@ouc.edu.cn
}

Keywords: SWOT analysis, crop straw, biomass briquette technology, biochar technology Abstract. An analysis of strength, weakness, opportunity, and threat (SWOT) was conducted to compare the management of crop straw using three different disposal methods including traditional household energy utilization, biomass briquette technology and biochar technology. The results indicated that the biomass briquette technology and the biochar technology showed significant advantages with higher energy utilization efficiency and less pollution compared with the technology of traditional household energy utilization. Moreover, the biochar technology had multiple benefits on carbon sequestration, soil amendment, pollution remediation and renewable energy production. However, more attention should be paid to the development and application of the biochar technology, as well as the policy support from governments. Considering all the factors, the biochar technology is the most promising method of crop straw disposal.

\section{Introduction}

Currently, the most widely used methods of crop straw disposal include the traditional household energy utilization (burning directly), biomass briquette technology and biochar technology. An analysis of strength, weakness, opportunity, and threat (SWOT) [1,2] was conducted to compare the management and development of crop straw using the three different methods, which could provide a theoretical foundation for policy makers.

\section{SWOT analysis of different methods of crop straw disposal}

About 800 million tons of crop straw are produced per year in China. A portion of these crop straw is processed and made into animal feed (about 25\%) and industry materials (about 2 3\%). In addition, $30 \%$ of the rest crop straw is utilized for the rural household energy, but still more than $35 \%$ of the crop straw is arbitrarily abandoned or disposed in the field $[3,4]$. The unreasonable methods of the crop straw disposal not only decrease the recovery efficiency of agricultural resource, but also result in serious environmental pollutions (e.g., atmospheric contamination, water eutrophication) and severe social issues. Therefore, it is urgent to develop a new technology to facilitate the comprehensive utilization of crop straw resources, which are of great practical significance for resource conservation, environmental protection, and sustainable development of agricultural production [1].

Traditional household energy utilization. Crop straw is considered as an important part of household energy in rural China. It is estimated that the crop straw accounts for $38.7 \%$ of total household energy consumption in 2000 [5]. Although crop straw is classified as carbon-neutral and renewable fuel, it is inefficiently utilized and produces pollutants during incomplete combustion (e.g. PMs, PAHs) [6]. The result of SWOT analysis is presented in Table 1. 
Table 1. SWOT analysis of traditional household energy utilization

\begin{tabular}{|c|c|c|c|}
\hline Strengths & Weaknesses & Opportunities & Threats \\
\hline $\begin{array}{l}\text { Abundant and } \\
\text { convenient source }\end{array}$ & Low efficiency & $\begin{array}{l}\text { Increasing demands } \\
\text { for rural household } \\
\text { energy }\end{array}$ & $\begin{array}{l}\text { Requirement on reducing the } \\
\text { emission of pollutants }\end{array}$ \\
\hline $\begin{array}{l}\text { Renewable and } \\
\text { carbon-neutral energy }\end{array}$ & Serious indoor air pollution & $\begin{array}{l}\text { Popularization of } \\
\text { improved stove }\end{array}$ & $\begin{array}{l}\text { Competition with emergence of } \\
\text { new technology }\end{array}$ \\
\hline $\begin{array}{l}\text { Low cost and less energy } \\
\text { inputs }\end{array}$ & $\begin{array}{l}\text { Time-consuming to collect } \\
\text { feedstock }\end{array}$ & & $\begin{array}{l}\text { Improvement of rural } \\
\text { environmental sanitation }\end{array}$ \\
\hline No secondary process & $\begin{array}{l}\text { Low density and larger space } \\
\text { for storing }\end{array}$ & & $\begin{array}{l}\text { Advocation of integrated crop } \\
\text { straw utilization }\end{array}$ \\
\hline
\end{tabular}

Biomass briquette technology. Biomass briquette of crop straw possesses comparative heat value of the middle-grade coal with the same density, which could be an excellent alternative fuel. Additionally, the pollutants released by biomass briquette is significantly less than that during the combustion of crop straw [7]. According to Renewable Energy Development Plan (2007), the annual usage of nationwide biomass briquette will amount to 1.0 million tons in 2020 [8]. Therefore, biomass briquette technology offers a very important direction of crop straw disposal. The result of SWOT analysis is shown in Table 2.

Table 2. SWOT analysis of biomass briquette technology

\begin{tabular}{|c|c|c|c|}
\hline Strengths & Weaknesses & Opportunities & Threats \\
\hline $\begin{array}{l}\text { Renewable and } \\
\text { carbon-neutral energy, less } \\
\text { carbon emission }\end{array}$ & $\begin{array}{l}\text { Easily to cause the damage of } \\
\text { instrument, high frequency of } \\
\text { maintenance and replacement } \\
\text { of instrument }\end{array}$ & $\begin{array}{l}\text { Replacement of coal saving } \\
\text { the energy and cutting the } \\
\text { emission }\end{array}$ & $\begin{array}{l}\text { Competition with } \\
\text { other technology for } \\
\text { the feedstock }\end{array}$ \\
\hline Abundant source & $\begin{array}{l}\text { More energy investment in } \\
\text { processing and transportation }\end{array}$ & Clear support of policy & $\begin{array}{l}\text { Immaturity of } \\
\text { biomass briquette } \\
\text { technology }\end{array}$ \\
\hline $\begin{array}{l}\text { Low cost, and easily to } \\
\text { application in the rural }\end{array}$ & $\begin{array}{l}\text { Seasonal change in the supply } \\
\text { of material and high cost of } \\
\text { storage and transportation }\end{array}$ & $\begin{array}{l}\text { Requirement of reducing } \\
\text { the pollutants produced by } \\
\text { household utilization }\end{array}$ & $\begin{array}{l}\text { Non-complete } \\
\text { production chain }\end{array}$ \\
\hline $\begin{array}{l}\text { High density, small size, } \\
\text { conveniently to store and } \\
\text { transport }\end{array}$ & $\begin{array}{l}\text { Improvement of industrial } \\
\text { furnaces or application of } \\
\text { specialized stoves }\end{array}$ & $\begin{array}{l}\text { Demand for the } \\
\text { development of renewable } \\
\text { energy }\end{array}$ & $\begin{array}{l}\text { Unsmooth } \\
\text { implementation of } \\
\text { related policy }\end{array}$ \\
\hline $\begin{array}{l}\text { High energy utilization } \\
\text { efficiency and less pollutant } \\
\text { emission }\end{array}$ & $\begin{array}{l}\text { Sintering and slagging at high } \\
\text { temperature, depositing and } \\
\text { corroding at low temperature }\end{array}$ & & \\
\hline High economic value & & & \\
\hline
\end{tabular}

Biochar technology. Biochar can be used as slow release fertilizer, and as soil amendment to promote chemical fertilizer utilization efficiency [9]. Moreover, the byproducts including bio-oil and syngas produced during the pyrolysis process are promising bio-fuels. The carbon sequestration of biochar application is beneficial for environmental protection, energy conservation and carbon emissions reduction. The result of SWOT analysis is shown in Table 3. 
Table 3 SWOT analysis of biochar technology

\begin{tabular}{|c|c|c|c|}
\hline Strengths & Weaknesses & Opportunities & Threats \\
\hline $\begin{array}{l}\text { Carbon-negative technology, } \\
\text { carbon sequestration }\end{array}$ & $\begin{array}{l}\text { High cost for } \\
\text { collecting, storing and } \\
\text { transporting biomass }\end{array}$ & $\begin{array}{l}\text { Requirement of carbon } \\
\text { sequestration and energy } \\
\text { conservation }\end{array}$ & $\begin{array}{l}\text { Difficulty in large-scale } \\
\text { production }\end{array}$ \\
\hline $\begin{array}{l}\text { Mitigating greenhouse gas } \\
\text { emission from soils }\end{array}$ & $\begin{array}{l}\text { Difficulty in large-scale } \\
\text { production }\end{array}$ & $\begin{array}{l}\text { Demand for remediating } \\
\text { contaminated soils }\end{array}$ & $\begin{array}{l}\text { Competition with other } \\
\text { energy technology for the } \\
\text { feedstock }\end{array}$ \\
\hline $\begin{array}{l}\text { Improving soil quality, } \\
\text { promoting crop productivity }\end{array}$ & $\begin{array}{l}\text { Irreversibility in } \\
\text { biochar application }\end{array}$ & $\begin{array}{l}\text { Demand for development } \\
\text { of country and support by } \\
\text { governmental policy }\end{array}$ & $\begin{array}{l}\text { Lack of carbon emission } \\
\text { trading market, }\end{array}$ \\
\hline $\begin{array}{l}\text { Remediating contaminated } \\
\text { soils }\end{array}$ & $\begin{array}{l}\text { Uncertainty of the } \\
\text { effect of biochar } \\
\text { application }\end{array}$ & $\begin{array}{l}\text { Demand for rural clean } \\
\text { energy }\end{array}$ & $\begin{array}{l}\text { Less confidence in biochar } \\
\text { product for farmers }\end{array}$ \\
\hline $\begin{array}{l}\text { Supplying nutrient for crops, } \\
\text { reducing nutrients leaching, } \\
\text { increasing nutrient utilization } \\
\text { efficiency }\end{array}$ & $\begin{array}{l}\text { Variability of biochar } \\
\text { properties and soil } \\
\text { condition }\end{array}$ & $\begin{array}{l}\text { Demand for decreasing } \\
\text { agricultural production } \\
\text { costs and increasing } \\
\text { farmers' income }\end{array}$ & \\
\hline $\begin{array}{l}\text { High-value byproduct (bio-oil } \\
\text { and syngas) }\end{array}$ & $\begin{array}{l}\text { Complicated properties } \\
\text { of biochars }\end{array}$ & & \\
\hline
\end{tabular}

\section{Results and discussion}

According to the analysis of traditional household energy utilization, biomass briquette technology and biochar technology by SWOT, the results are shown below. Firstly, although the traditional household energy utilization could meet the requirement of rural household energy to a certain extent, it would increase the emissions of pollutants, especially PMs and PAHs, which have critical impacts on human health and environment. In addition, its energy efficiency and adaptability to new energy are low. Consequently, it is imperative to change the traditional methods of crop straw disposal. Secondly, the biomass briquette technology is an advanced energy utilization of crop straw, and the biggest advantage is that it can significantly promote the quality of products from crop straw by secondary processing and increase the energy efficiency, thus to replace the coal well and reduce the pollutants emission. Moreover, the support by government policy is the key driving power of its development. However, the crude process technology limits development of the biochar technology. Thirdly, compared with the traditional household energy utilization and biomass briquette technology, the biochar technology contributes multiple benefits on carbon sequestration, soil amendment, pollution remediation and production of renew energy, which are hot issues about environment, agriculture and energy. Hence biochar is considered as sustainable technology with high performance of integration [10,11]. Tejerina [12] compared the biochar and bioenergy technology with traditional disposal technology of maize straw using life cycle assessment and cost-benefit analysis, and found that biochar had obvious advantages on the greenhouse effect mitigation, net energy balance and economic benefit.

However, there are still several problems in biochar application. One of the problems is that the biochar properties are highly related to feedstocks and pyrolysis conditions, which leads to the uncertainties about biochar potential benefits when applied to soil as amendment. Therefore, it is the great challenge to establish standardized biochar technology at present. Additionally, considering different soil type and contamination, the designed biochar plays a very significant role in the future.

Biochar technology of crop straw is an integrated application that is able to mitigate climate change, increase agricultural productivity, ameliorate soil and water contamination and produce renew energy. Moreover, biochar has great potential to realize resourceful utilization and built sustainable agricultural recycle mode. Nevertheless, there are still much efforts to do about the development of biochar in the future. It should be paid much attention to strengthen the basic theory, evaluate the economic value, establish carbon trade market and develop production chain so as to obtain support of government policy better. 


\section{Acknowledgements}

This study was supported by National Natural Science Foundation of China (41406085, 41325013) and Ocean Public Welfare Scientific Research Project (201305021).

\section{References}

[1] Zhixiang Jiang, Assessment of the mitigation potential of greenhouse gas emissions for biochar technology: Ocean University of China, Qingdao, China (2013) in Chinese

[2] Hong Cheng, Jianzhong Gao, SWOT Analysis on agriculture carbon sequestration project with straw return to field as target: Journal of Anhui Agricultural Sciences Vol. 39 (2011), p. 19375 in Chinese

[3] Yuyun Bi, Chunyu Gao, Yajing Wang, Baoyu Li, Estimation of straw resources in China: Transactions of the CSAE Vol. 25 (2009), p. 211 in Chinese

[4] Yuyun Bi, Jianping Kou, Daolong Wang et al., in: The comprehensive utilization of straw resource in China, edited by China Agricultural Science \& Technology Press (2008)

[5] Yishui Tian, The development status and trends in rural China in 2013: China Energy Vol. 36 (2014), p.10 in Chinese

[6] Siye Wei, Guofeng Shen, Yanyan Zhang, et al., Field measurement on the emissions of PM, OC, EC and PAHs from indoor crop straw burning in rural China: Environmental Pollution Vol. 184 (2014), p. 18

[7] Guofeng, Shen, Miao Xue, Comparison of Carbon Monoxide and Particulate Matter Emissions from Residential Burnings of Pelletized Biofuels and Traditional Solid Fuels: Energy \& Fuels Vol. 28 (2014), p. 3933

[8] Information on http://www.sdpc.gov.cn/

[9] Dandan Wang, Jiyong Zheng, Yonghao Yan, Xingchang Zhang, Effect of biochar application on soil water holding capacity in the southern region of Ningxia: Journal of Soil and Water Conservation Vol. 27 (2012), p. 101 in Chinese

[10]Saran Sohi, Elisa Lopez-Capel, Evelyn Krul, Roland Bol, in: Biochar, climate change and soil a review to guide future research, CSIRO Land and Water Science Report series (2009)

[11]Johannes Lehmann, Stephen Joseph, in: Biochar for environmental management: An introduction, edited by Johannes Lehmann, Stephen Joseph, in Biochar for environmental management science and technology (Second Edition), chapter, 1, Routledge (2015)

[12]M.R. Tejerina, Biochar as a strategy for sustainable land management, poverty reduction and climate change mitigation/adaptation? Thermolysis of lignin for value-added products: Vrije Universiteit, Amsterdam, the Netherlands (2010) 